\title{
Cytotoxicity of one-step dentin-bonding agents toward dental pulp and odontoblast-like cells
}

\author{
Y. YASUDA*, H. INUYAMA*, H. MAEDA ${ }^{\dagger}, A \cdot A K A M I N E+, J \cdot E \cdot \mathrm{NÖR}^{\ddagger} \varepsilon$ T. SAITO* \\ *Division of Clinical Cariology and Endodontology, Department of Oral Rehabilitation, School of Dentistry, Health Sciences University of \\ Hokkaido, Hokkaido, Japan, ${ }^{\dagger}$ Division of Endodontology and Operative Dentistry, Faculty of Dental Science, Kyushu University, Fukuoka, \\ Japan and ${ }^{\ddagger}$ Angiogenesis Research Laboratory, Department of Restorative Sciences, University of Michigan School of Dentistry, Ann Arbor, MI, \\ USA
}

SUMMARY The purpose of this study was to compare the cytotoxicity of five one-step dentin-bonding agents on human dental pulp and odontoblast-like cells (MDPC-23). Photopolymerized and unpolymerized samples of these dentin-bonding agents were prepared and incubated with dental pulp or MDPC-23 cells. After 24 or $72 \mathrm{~h}$ of incubation, the number of unstained cells with trypan blue was counted. The staining of cells with trypan blue stands for a cytotoxicity. The pulp cell and MDPC23 cytotoxicity of polymerized sample treatment increased in the order of AQ Bond Plus (AQ)<Clearfil Tri-S Bond (TS)=G-bond $(\mathrm{GB})<$ Absolute (AB)<Adper Prompt (AP) for 24 and $72 \mathrm{~h}$. The pulp cell cytotoxicity of unpolymerized sample treatment for $24 \mathrm{~h}$ increased in the order of $A Q<G-$ $B=A B<T S<A P$. The MDPC-23 cytotoxicity of unpolymerized sample treatment for $24 \mathrm{~h}$ increased in the order of $A Q<G B<T S=A B<A P$. Whether polymerized or unpolymerized, AQ was the least cytotoxic agent, while AP was the strongest. All polymerized dentin-bonding agents exhibited lower cytotoxicity by $2-65 \%$ than their unpolymerized counterparts. The appearance of the cytotoxicity of dentin-bonding agents was time-dependent, and cell viability was lower at $72 \mathrm{~h}$ by $2-46 \%$ than at $24 \mathrm{~h}$. The cytotoxicity to MDPC-23 cells was about 5-24\% higher than that to pulp cells. These results indicate that one-step dentin-bonding agents differ markedly in their cytotoxicity. Differential cytotoxic effects of one-step dentin-bonding agents should be considered during clinical application of operative restoration.

KEYWORDS: one-step dentin-bonding agents, dental pulp cells, odontoblasts, trypan blue staining, cell viability, photopolymerization

Accepted for publication 8 April 2008

\section{Introduction}

Minimal intervention (MI) has become the preferred treatment for caries with recent advances in dentinbonding agents $(1,2)$. If their bonding strength is weak, then microleakage can occur, thereby affecting the survival of the teeth $(3,4)$. Bonding agent-induced dental pulp inflammation has been demonstrated histopathologically (5). This pulp reaction is considered to be caused by the diffusion from dental tubules of unpolymerized monomers remaining after photopolymerization $(6,7)$. Unpolymerized monomers may come in direct contact with odontoblasts and pulp cells. Furthermore, the monomers have been recognized as antigen and induced inflammatory reactions in the pulp tissue (8).

In the past, many studies have investigated the influence of dental restorative materials on dental pulp cells $(9,10)$. In particular, methods of screening for cytotoxicity in cultured cells are widely used 
because of their inexpensiveness and high reproducibility (11-15). Their cytotoxicity has been evaluated in terms of changes in cell number, membrane permeability, intracellular metabolism and cell morphology. Cytotoxicity was detected in most of the previously investigated bonding agents. Clearfil SE bond was less cytotoxic than Prime $\&$ Bond and Single Bond on human pulp cells (16), and Scotchbond 1 was reported to be more toxic than Syntac Sprint and Prime \& Bond (17). Chen et al. reported that Syntac Sprint was more toxic than Prime \& Bond and Single Bond (18). Based on these findings, Scotchbond 1 is the most toxic and Clearfil SE bond is the least toxic. Furthermore, various monomers comprising dentin-bonding agents have been compared regarding cytotoxicity in cultured cell systems. Ratanasathien et al. reported that 2,2-bis[4'-(x-hydroxy-3'-methacryloyoxy)phenyl] propane (bis-GMA) showed the highest toxicity against mouse fibroblasts, followed by urethane dimethacrylate (UDMA), triethylene-glycoldimethacrylate (TEGDMA) and 2-hydroxyethyl methacrylate (HEMA) in order of decreasing toxicity (19). In a comparison of 35 resin components concerning cytotoxicity, Geurtsen et al. found that UDMA was more cytotoxic than TEGDMA on human gingival fibroblasts and periodontal ligament cells, but less toxic on human dental pulp cells (20). The biological effects of bonding agents have also been clarified. Recently, unpolymerized monomers have been reported to influence the immune system by inhibiting the secretion of cytokines from macrophages (21). Furthermore, dentin-bonding agents induce apoptosis and cell cycle arrest was noted in most cells that escaped from apoptosis (22).

One-step bonding agents have been developed and shown to exhibit good bonding strength despite their easier handling properties compared with two-step bonding agents $(23,24)$. However, little is known about the cytotoxicity of one-step bonding agents, compared with two-step bonding agents. Moreover, no comparison has been made between their cytotoxicity before and after polymerization. We hypothesized that the cytotoxicity varies among one-step dentin-bonding agents because each component exhibits different cytotoxicity. To confirm our hypothesis, we selected five one-step dentin-bonding agents consisting of different solvents and component monomers. The purpose of this study was to compare the cytotoxicity of five one-step dentin-bonding agents on human dental pulp and MDPC-23 cells.

\section{Materials and methods}

\section{Dentin-bonding agents}

Five one-step dentin-bonding agents consisting of different solvents and component monomers were selected. Absolute (AB),* Adper Prompt (AP), ${ }^{+} \mathrm{AQ}$ Bond Plus (AQ), ${ }^{\ddagger}$ G-bond $(\mathrm{GB})^{\S}$ and Clearfil Tri-S Bond (TS). ${ }^{\mathbb{T}}$ Their components are listed in Table 1.

\section{Cells and cell culture conditions}

Human dental pulp cells were obtained from the healthy third molars which were extracted during normal treatment (19 to 21-year-old patients). The protocol for these experiments was reviewed and approved by the Health Sciences University of Hokkaido Research Ethics Committee, and informed consent was obtained from the tissue donors. To avoid the contamination of experimental materials with gingival tissues and the periodontal ligament attached to the tooth, any residues of these were carefully removed before further processing. The teeth were placed into calcium-free and magnesium-free phosphate-buffered saline (PBS),** and scored sagittaly with a sterile diamond bur flushed with PBS and open. The pulp cells were prepared by pooling pulps collected from three patients. The extruded pulp tissues were rinsed once in PBS and cut into $2-\mathrm{mm}^{3}$ cubes using a dental surgical knife. Next, the fragmented pulp tissues were digested with $2 \mathrm{mg} \mathrm{mL}^{-1}$ collagenase and $0 \cdot 25 \%$ tripsin at $37{ }^{\circ} \mathrm{C}$ for $30 \mathrm{~min}$. The resultant suspension was then centrifuged to collect the released cells. These cells were subsequently cultured in Dulbecco's Modified Eagle's Medium (DMEM), ${ }^{+\dagger}$ supplemented with $10 \%$ fetal bovine serum, ${ }^{++} 10000 \mathrm{U} \mathrm{mL}^{-1}$ penicillin $^{\ddagger \neq}$ and $10 \mathrm{mg} \mathrm{mL}^{-1}$ streptomycin ${ }^{\ddagger \ddagger}$ at $37^{\circ} \mathrm{C}$ in a humidified atmosphere of $5 \% \mathrm{CO}_{2}$. All experiments were per-

\footnotetext{
*Dentsply, Tokyo, Japan.

†3M ESPE, St Paul, MN, USA.

${ }^{\ddagger}$ Sun Medical, Moriyama, Japan.

$\S_{\text {GC, Tokyo, Japan. }}$

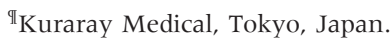

**Invitrogen, Carlsbad, CA, USA.

${ }^{++}$Sigma, St Louis, MI, USA.

${ }^{\ddagger \ddagger}$ GIBCO, Invitrogen, Grand Island, NY, USA.
} 
Table 1. The components of the five one-step dentin-bonding agents tested

\begin{tabular}{lll}
\hline $\begin{array}{l}\text { One-step } \\
\text { dentin-bonding agent }\end{array}$ & Components & $\begin{array}{l}\text { Lot } \\
\text { number }\end{array}$ \\
\hline Absolute (AB) & 4-MET, methacryloxyethyl pyrophosphate-fluoridated filler, SiO ${ }_{2}$, initiator, acetone & $\begin{array}{l}\text { 409-029 } \\
\text { Adper Prompt (AP) }\end{array}$ \\
AQ Bond Plus (AQ) & Bethacrylated phosphoric acid esters, bis-GMA, HEMA, water & LW3 \\
& Sodium $p$-toluensulfinate & 0403021 \\
G-Bond (GB) & 4-MET, phosphate ester, di-methacrylate, water, acetone, initiator & 011174 \\
Clearfil Tri-S Bond (TS) & MDP, bis-GMA, HEMA, microfiller, initiator, ethanol, water & \\
\hline
\end{tabular}

4-MET, 4-methacryloxyethyl trimellitic acid; 4-META, 4-methacryloxyethyl trimellitate anhydride;

MDP, 10-methacryloxydecyl dihydrogen phosphate; HEMA, 2-hydroxyethyl methacrylate; bis-GMA, 2,2-bis[4'-(x-hydroxy-3'-methacryloyoxy)phenyl] propane.

formed on human dental pulp cells between passages 5 and 8.

MDPC-23 is a cell line established from dental papilla cells of 18 to 19 foetal day CD-1 mouse mandibular first molars by Hanks et al. (25). The cells were cultured by the standard method for pulp cells using DMEM. The cells have properties of odontoblast precursor cells, being characterized by high alkaline phosphatase (ALP) activity. We confirmed the retention of this property every passage.

\section{Sample preparation}

Two microliters of each dentin-bonding agent were placed with a micropipette in the centre of each well of a 6-well plate and irradiated with a halogen irradiator. Regarding the irradiation conditions, AQ was exposed for $5 \mathrm{~s}$, and the other materials for $10 \mathrm{~s}$, following the manufacturer's instructions. Each well was seeded with a $2 \mathrm{~mL}$ suspension of cells at a concentration of $2 \times 10^{5}$ cells $\mathrm{mL}^{-1}$. The same cell suspension was dispensed into wells without a dentin-bonding agent to serve as controls. In another group of similar wells, dentinbonding agents were not irradiated before placing the cells. Plates were incubated at $37^{\circ} \mathrm{C}$ for 24 and $72 \mathrm{~h}$. The $\mathrm{pH}$ of media containing polymerized or unpolymerized agents was measured by $\mathrm{pH}$ meter. ${ }^{\text {} \$}$

\section{Cell viability assay}

After culture, the medium was transferred to a tube and floating cells were collected. The adherent cells were removed by $0 \cdot 25 \%$ trypsin treatment for $5 \mathrm{~min}$ and

\footnotetext{
${ }^{\$ \varsigma}$ Horiba Instruments Ltd, Kyoto, Japan.
}

transferred to the same tube. The tube was centrifuged, the supernatant was removed, and all cells were suspended in PBS. The absence of residual cells in the well or supernatant was confirmed under a microscope. The cells were then stained with trypan blue (Sigma), and the unstained cells were counted with haemocytometer chamber under a light microscope. The cell viability was calculated as a percentage using the following formula:

$$
\text { Percentage of viable cells }=(\mathrm{A} / \mathrm{B}) \times 100
$$

where $A$ is the number of viable cells in the experimental well and $B$ is that in the control well.

\section{Statistical analysis}

A statistical analysis was performed with the data obtained from three independent experiments. The data are expressed as the mean \pm s.d. and analyzed using One-way analysis of variance (ANOva) followed by Tukey's multiple comparison tests, and a value of $P<0.05$ was considered to be significant.

\section{Results}

Table 2 shows the cytotoxicity of polymerized and unpolymerized one-step dentin-bonding agents toward human dental pulp cells. The cell count of untreated human pulp cells was $2.49 \times 10^{5}$ after $24 \mathrm{~h}$ and $3.90 \times 10^{5}$ after $72 \mathrm{~h}$. The pulp cell viability after treatment with polymerized $\mathrm{AB}, \mathrm{AP}, \mathrm{AQ}, \mathrm{GB}$ and $\mathrm{TS}$ for $24 \mathrm{~h}$ were $50 \cdot 6 \pm 7 \cdot 2 \%, 12 \cdot 4 \pm 8 \cdot 8 \%, 88 \cdot 8 \pm 9 \cdot 2 \%$, $63.5 \pm 17 \cdot 7 \%$ and $67.5 \pm 10.4 \%$, respectively, and those after $72 \mathrm{~h}$ were $7 \cdot 9 \pm 4 \cdot 9 \%, 0 \%, 60 \cdot 3 \pm 3 \cdot 1 \%$, $26 \cdot 2 \pm 3 \cdot 8 \%$ and $21 \cdot 0 \pm 2 \cdot 1 \%$, respectively. The pulp cell cytotoxicity of polymerized sample treatment 
Table 2. The cytotoxicity of five one-step dentin-bonding agents toward human dental pulp cells

\begin{tabular}{|c|c|c|c|c|}
\hline \multirow[b]{2}{*}{ Materials } & \multicolumn{2}{|l|}{$24 \mathrm{~h}$} & \multicolumn{2}{|l|}{$72 \mathrm{~h}$} \\
\hline & Polymerized & Unpolymerized & Polymerized & Unpolymerized \\
\hline \multirow[t]{2}{*}{ Absolute } & $1 \cdot 26(0 \cdot 18)$ & $0.69(0 \cdot 21)$ & $0 \cdot 31(0 \cdot 19)$ & 0 \\
\hline & $50 \cdot 6 \%(7 \cdot 2 \%)^{c}$ & $27 \cdot 7 \%(8 \cdot 4 \%)^{\mathrm{b}}$ & $7 \cdot 9 \%(4.9 \%)^{c}$ & $0 \%$ \\
\hline \multirow[t]{2}{*}{ Adper Prompt } & $0 \cdot 31(0 \cdot 22)$ & 0 & 0 & 0 \\
\hline & $12 \cdot 4 \%(8 \cdot 8 \%)^{\mathrm{d}}$ & $0 \%$ & $0 \%$ & $0 \%$ \\
\hline \multirow[t]{2}{*}{ AQ Bond Plus } & $2 \cdot 21(0 \cdot 23)$ & $1 \cdot 28(0 \cdot 19)$ & $2 \cdot 35(0 \cdot 12)$ & $0 \cdot 22(0 \cdot 12)$ \\
\hline & $88 \cdot 8 \%(9 \cdot 2 \%)^{a}$ & $51 \cdot 4 \%(7 \cdot 6 \%)^{a}$ & $60 \cdot 3 \%(3 \cdot 1 \%)^{a}$ & $5 \cdot 6 \%(3 \cdot 1 \%)$ \\
\hline \multirow[t]{2}{*}{ G-bond } & $1.58(0.44)$ & $0 \cdot 60(0 \cdot 15)$ & $1 \cdot 02(0 \cdot 15)$ & 0 \\
\hline & $63 \cdot 5 \%(17 \cdot 7 \%)^{\mathrm{b}}$ & $24 \cdot 1 \%(6 \cdot 0 \%)^{\mathrm{b}}$ & $26 \cdot 2 \%(3 \cdot 8 \%)^{\mathrm{b}}$ & $0 \%$ \\
\hline Clearfil Tri-S & $1 \cdot 68(0 \cdot 26)$ & $0.07(0.05)$ & $0.82(0.08)$ & 0 \\
\hline Bond & $67 \cdot 5 \%(10 \cdot 4 \%)^{b}$ & $2 \cdot 8 \%(2 \cdot 0 \%)^{\mathrm{c}}$ & $21 \cdot 0 \%(2 \cdot 1 \%)^{\mathrm{b}}$ & $0 \%$ \\
\hline
\end{tabular}

Data are shown as the number of viable cells (upper; $\times 10^{5}$ cells) and percentage of viable cells compared with the control (lower) at 24 and $72 \mathrm{~h}$ in photopolymerized and unpolymerized groups $(n=3)$. Data are expressed as the mean (s.d.) and were analyzed using Oneway analysis of variance (ANOva) followed by the Tukey's multiple comparison tests. $P<0 \cdot 05$ was considered to be significant.

$\mathrm{a}, \mathrm{b}, \mathrm{c}, \mathrm{d}$ Different letters indicate significant differences between groups.

increased in the order of $\mathrm{AQ}<\mathrm{TS}=\mathrm{GB}<\mathrm{AB}<\mathrm{AP}$ for 24 and $72 \mathrm{~h}$. The cytotoxicity of unpolymerized sample treatment for $24 \mathrm{~h}$ increased in the order of $\mathrm{AQ}<\mathrm{AB}=\mathrm{GB}<\mathrm{TS}<\mathrm{AP}$, and no viable cell after treatment for $72 \mathrm{~h}$ excluding AQ treatment was found. The viable rates of human pulp cells treated with the unpolymerized AQ for $24 \mathrm{~h}(P<0.01)$, AQ for $72 \mathrm{~h}(P<0.001)$, GB for $24 \mathrm{~h}(P<0.01)$ and TS for $24 \mathrm{~h}(P<0.001)$ were significantly lower than those treated with the polymerized samples by $37-65 \%$.

Next, the cytotoxicity of one-step bonding agents was evaluated in the MDPC-23 odontoblast-like cells
(Table 3). The cell count of untreated MDPC-23 was $2.61 \times 10^{5}$ after $24 \mathrm{~h}$ and $4.10 \times 10^{5}$ after $72 \mathrm{~h}$. The MDPC-23 cell viability after treatment with polymerized $\mathrm{AB}, \mathrm{AP}, \mathrm{AQ}, \mathrm{GB}$ and $\mathrm{TS}$ for $24 \mathrm{~h}$ were $26 \cdot 1 \pm 4 \cdot 6 \%, 0 \%, 82 \cdot 0 \pm 12 \cdot 6 \%, 42 \cdot 5 \pm 13.4 \%$ and $44.8 \pm 5.4 \%$, respectively, and those after $72 \mathrm{~h}$ were $1 \cdot 7 \pm 2 \cdot 0 \%, \quad 0 \%, \quad 38.0 \pm 4 \cdot 1 \%, \quad 6.3 \pm 3.2 \% \quad$ and $12 \cdot 0 \pm 2 \cdot 7 \%$, respectively. The MDPC-23 cytotoxicity of polymerized sample treatment for 24 and $72 \mathrm{~h}$ increased in the order of $\mathrm{AQ}<\mathrm{TS}=\mathrm{GB}<\mathrm{AB}<\mathrm{AP}$. The cytotoxicity of unpolymerized sample treatment for $24 \mathrm{~h}$ increased in the order of $\mathrm{AQ}<\mathrm{GB}<\mathrm{TS}=\mathrm{AB}<\mathrm{AP}$,

Table 3. The cytotoxicity of five one-step dentin-bonding agents toward MDPC-23 odontoblast-like cells

\begin{tabular}{|c|c|c|c|c|}
\hline \multirow[b]{2}{*}{ Materials } & \multicolumn{2}{|l|}{$24 \mathrm{~h}$} & \multicolumn{2}{|l|}{$72 \mathrm{~h}$} \\
\hline & Polymerized & Unpolymerized & Polymerized & Unpolymerized \\
\hline \multirow[t]{2}{*}{ Absolute } & $0 \cdot 68(0 \cdot 12)$ & $0 \cdot 12(0 \cdot 04)$ & $0 \cdot 07(0 \cdot 08)$ & 0 \\
\hline & $26 \cdot 1 \%(4 \cdot 6 \%)^{c}$ & $4.6 \%(1.5 \%)^{\mathrm{c}}$ & $1.7 \%(2 \cdot 0 \%)^{\mathrm{c}}$ & $0 \%$ \\
\hline \multirow[t]{2}{*}{ Adper Prompt } & 0 & 0 & 0 & 0 \\
\hline & $0 \%$ & $0 \%$ & $0 \%$ & $0 \%$ \\
\hline \multirow[t]{2}{*}{ AQ Bond Plus } & $2 \cdot 14(0.33)$ & $1 \cdot 12(0 \cdot 16)$ & $1 \cdot 56(0 \cdot 17)$ & $0 \cdot 16(0 \cdot 11)$ \\
\hline & $82 \cdot 0 \%(12 \cdot 6 \%)^{a}$ & $43 \cdot 0 \%(6 \cdot 1 \%)^{a}$ & $38 \cdot 0 \%(4 \cdot 1 \%)^{\mathrm{a}}$ & $3 \cdot 9 \%(2 \cdot 7 \%)$ \\
\hline \multirow[t]{2}{*}{ G-bond } & $1 \cdot 11(0 \cdot 35)$ & $0.44(0.07)$ & $0 \cdot 26(0 \cdot 13)$ & 0 \\
\hline & $42 \cdot 5 \%(13.4 \%)^{b}$ & $16 \cdot 9 \%(2 \cdot 7 \%)^{\mathrm{b}}$ & $6 \cdot 3 \%(3 \cdot 2 \%)^{b}$ & $0 \%$ \\
\hline Clearfil Tri-S & $1 \cdot 17(0 \cdot 14)$ & $0 \cdot 15(0 \cdot 05)$ & $0 \cdot 49(0 \cdot 11)$ & 0 \\
\hline Bond & $44 \cdot 8 \%(5 \cdot 4 \%)^{\mathrm{b}}$ & $5 \cdot 7 \%(1.9 \%)^{c}$ & $12 \cdot 0 \%(2 \cdot 7 \%)^{\mathrm{b}}$ & $0 \%$ \\
\hline
\end{tabular}

Data are shown as the number of viable cells (upper; $\times 10^{5}$ cells) and percentage of viable cells compared with the control (lower) at 24 and $72 \mathrm{~h}$ in photopolymerized and unpolymerized groups $(n=3)$. Data are expressed as the mean (s.d.) and were analyzed using Oneway analysis of variance (ANOVA) followed by the Tukey's multiple comparison tests. $P<0.05$ was considered to be significant. $\mathrm{a}, \mathrm{b}, \mathrm{c}, \mathrm{d}$ Different letters indicate significant differences between groups. 
and no viable cell after treatment for $72 \mathrm{~h}$ excluding AQ treatment was found. The viable rates of MDPC cells treated with the unpolymerized $\mathrm{AB}$ for $24 \mathrm{~h}$ $(P<0.01)$, AQ for $24 \mathrm{~h}(P<0.001)$, AQ for $72 \mathrm{~h}$ $(P<0.001), \quad$ GB for $24 \mathrm{~h} \quad(P<0.01)$ and TS for $24 \mathrm{~h}(P<0.001)$ were significantly lower than those treated with the polymerized samples by $21-40 \%$.

Whether polymerized or unpolymerized, AQ exhibited the lowest cytotoxicity, while AP exhibited the highest. The appearance of the cytotoxicity of dentinbonding agents was time-dependent, and cell viability was lower at $72 \mathrm{~h}$ by $2-46 \%$ than at $24 \mathrm{~h}$. The viable rates of MDPC cells treated with polymerized $A B$ for $24 \mathrm{~h}(P<0.01)$, GB for $72 \mathrm{~h}(P<0.05)$ and TS for $24 \mathrm{~h}$ $(P<0.01)$, and that treated with unpolymerized $\mathrm{AB}$ for $24 \mathrm{~h}(P<0.01)$ were significantly lower than those of pulp cells by $20-24 \%$. No significant differences were noted in cells treated with other samples.

The $\mathrm{pH}$ of media after $24 \mathrm{~h}$ of treatment with polymerized samples, $\mathrm{AB}, \mathrm{AP}, \mathrm{AQ}, \mathrm{GB}$ and $\mathrm{TS}$ was $6 \cdot 47,6 \cdot 23,7 \cdot 07,6.73$ and 6.95 , respectively. The $\mathrm{pH}$ of media added unpolymerized samples, AB, AP, AQ, GB and TS was $6 \cdot 21,5 \cdot 84,6 \cdot 86,6 \cdot 51$ and $6 \cdot 60$, respectively. The $\mathrm{pH}$ was $0 \cdot 2-0 \cdot 4$ lower in the media the unpolymerized samples.

\section{Discussion}

To date, the mouse fibroblast cell line L929 (11), human fibroblasts $(12,13)$, human dental pulp cells $(16,18)$ and the mouse odontoblast-like cell line MDPC-23 $(14,15)$ have been used to test the cytotoxicity of dentin-bonding agents. In this study, to evaluate their cytotoxicity on dental pulp tissue, we used the dental pulp and MDPC-23 cells because these cells mainly constitute pulp tissue. As it was difficult to isolate odontoblasts from crowns, an odontoblast-like cell line was used. The toxicity to MDPC-23 cells was about $5-24 \%$ higher than that to pulp cells, but the reason for it: whether it was because of cell differentiation, cultured cell line or species difference could not clarified in this study.

MDPC-23 is known to have mineralization ability (25). These cells are very useful for analyzing the mechanism of calcification by odontoblasts (26). In control cells to which no extracts from dentin-bonding agents were added, the ALP activity peaked on day 4 and decreased thereafter. Although we examined the influence of dentin-bonding agents on cell differentia- tion, even polymerized samples were so cytotoxic that we were not able to culture cells for a long period of time. It was difficult to ascribe the inhibition of ALP activity to the inhibition of cell differentiation or cell damage.

The viability of human dental pulp and MDPC-23 cells incubated with a polymerized AQ for $24 \mathrm{~h}$ were the highest at $88 \%$ and $82 \%$, respectively, among the dentin-bonding agents tested. AQ is characterized by the lower acidity of phosphate ester monomers and the thinner hybrid layer compared with other dentinbonding agents (27). Acid removal from the medium reduced the cytotoxicity in a previous report (15). Furthermore, we found in this study that on measurement of the culture medium $\mathrm{pH}$, the toxicity increased as the acidity increased. These results suggest that the cytotoxicity may be because of a shift of medium $\mathrm{pH}$ toward acidic. The differences in the component monomer type and concentration may have affected the cytotoxicity. Unpolymerized $\mathrm{AP}$ and TS exhibited relatively high cytotoxicity, suggesting that bis-GMA may have strong toxicity among the monomers, as previously reported (19). In an experimental system in which unpolymerized bonding agents were directly added to cell cultures, all bonding agent samples showed a higher cytotoxicity than equal volumes of their polymerized counterparts. This is in agreement with the previous report (28) that polymerized resins released fewer polymers and were less stimulatory and completely polymerized resins were non-stimulatory.

We analyzed the cell viability using the trypan blue staining method. This dye strongly binds to protein. It passes through injured cell membranes, and specifically stains the dead cells. The viable cell rate can be calculated by counting the unstained cells using a haemocytometer. The 3-(4,5-Dimethylthiazol-2-yl)2,5-diphenyltetrazolium bromide method measuring succinic dehydrogenase (SDH) activity is generally used as a simple method for investigating cytotoxicity. However, we stained the cells with trypan blue according to previous reports (29) as the residual monomers may affect the medium colour. Cellular SDH activity measurement may also be necessary.

Regarding the irradiation conditions, a halogen irradiator was used. AQ was exposed for $5 \mathrm{~s}$ and the other materials for $10 \mathrm{~s}$, following the manufacturer's instructions. For comparison with other studies, the ISO guidelines should be followed, but we followed the 
instructions for each material because the protocol specified in the instructions may maximize the specific properties of the material. Furthermore, inhibition of polymerization by oxygen was also considered (30), but we did not employ irradiation in the presence of nitrogen or coverage by glycerol. Therefore, it cannot be ruled that the polymerized samples may exhibit stronger toxicity.

Recently, dentin-bonding agents have been suggested as replacement for calcium hydroxide for pulpal protection (31). The dentin-bonding agents were observed to seal the exposed dental pulp and induce the formation of repaired dentin (32). On the other hand, studies reported that dentin-bonding agents induced persistent inflammation in pulpal tissue and completely inhibited the repair process (33). Therefore, it is desirable that dentin-bonding agents not only exhibit strong bonding strength, but also are harmless to dental pulp, and do not inhibit the differentiation of dental pulp cells into odontoblasts to promote the formation of repaired dentin in the dental pulp.

In conclusion, we found that AQ was the least cytotoxic while AP was most toxic among the five onestep dentin-bonding agents examined. A sufficient thickness of the hybrid layer may be obtained as the monomer acidity increases, strengthening adhesive force (34). Therefore, consideration is necessary for clinical application such as application of AP for Class IV cavities requiring strong adhesive force and less toxic AQ for deep cavities.

\section{Acknowledgments}

This work was supported by Grants-in-Aid for Scientific Research (Nos. 18659563 and 18791407) from the Japan Society for the Promotion of Science and by a grant from the Research Center, Health Sciences University of Hokkaido, Japan.

\section{References}

1. Mount GJ. Minimal intervention dentistry: rationale of cavity design. Oper Dent. 2003;28:92-99.

2. Peters MC, McLean ME. Minimally invasive operative care. I. Minimal intervention and concepts for minimally invasive cavity preparations. J Adhes Dent. 2001;3:7-16.

3. Gladys S, Van Meerbeek B, Lambrechts P, Vanherle G. Microleakage of adhesive restorative materials. Am J Dent. 2001;14:170-176.
4. Peumans M, De Munck J, Van Landuyt K, Lambrechts P, Van Meerbeek B. Five-year clinical effectiveness of a two-step selfetching adhesive. J Adhes Dent. 2007;9:7-10.

5. Murray PE, Hafez AA, Smith AJ, Cox CF. Bacterial microleakage and pulp inflammation associated with various restorative materials. Dent Mater. 2002;18:470-478.

6. Gerzina TM, Hume WR. Diffusion of monomers from bonding resin-resin composite combinations through dentine in vitro. J Dent. 1996;24:125-128.

7. Hamid A, Hume WR. The effect of dentine thickness on diffusion of resin monomers in vitro. $\mathrm{J}$ Oral Rehabil. 1997; 24:20-25.

8. Harnirattisai C, Hosoda H. Pulpal responses to various dentin bonding systems in dentin cavities. Dent Mater J. 1991;10:149-164.

9. al-Dawood A, Wennberg A. Biocompatibility of dentin bonding agents. Endod Dent Traumatol. 1993;9:1-7.

10. Mjor IA. Biologic assessment of restorative dental materials: interrelationship of biologic and technologic properties. Oper Dent. 1978;3:9-13.

11. Kaga M, Noda M, Ferracane JL, Nakamura W, Oguchi H, Sano $\mathrm{H}$. The in vitro cytotoxicity of eluates from dentin bonding resins and their effect on tyrosine phosphorylation of L929 cells. Dent Mater. 2001;17:333-339.

12. Schedle A, Franz A, Rausch-Fan X, Spittler A, Lucas T, Samorapoompichit $\mathrm{P}$ et al. Cytotoxic effects of dental composites, adhesive substances, compomers and cements. Dent Mater. 1998;14:429-440.

13. Hanks CT, Strawn SE, Wataha JC, Craig RG. Cytotoxic effects of resin components on cultured mammalian fibroblasts. J Dent Res. 1991;70:1450-1455.

14. de Souza Costa CA, Hebling J, Hanks CT. Effects of lightcuring time on the cytotoxicity of a restorative resin composite applied to an immortalized odontoblast-cell line. Oper Dent. 2003;28:365-370.

15. Costa CA, Vaerten MA, Edwards CA, Hanks CT. Cytotoxic effects of current dental adhesive systems on immortalized odontoblast cell line MDPC-23. Dent Mater. 1999;15:434441.

16. Huang FM, Chang YC. Cytotoxicity of dentine-bonding agents on human pulp cells in vitro. Int Endod J. 2002;35:905-909.

17. Szep S, Kunkel A, Ronge K, Heidemann D. Cytotoxicity of modern dentin adhesives - in vitro testing on gingival fibroblasts. J Biomed Mater Res. 2002;63:53-60.

18. Chen RS, Liu CC, Tseng WY, Jeng JH, Lin CP. Cytotoxicity of three dentin bonding agents on human dental pulp cells. J Dent. 2003;31:223-229.

19. Ratanasathien S, Wataha JC, Hanks CT, Dennison JB. Cytotoxic interactive effects of dentin bonding components on mouse fibroblasts. J Dent Res. 1995;74:1602-1606.

20. Geurtsen W, Lehmann F, Spahl W, Leyhausen G. Cytotoxicity of 35 dental resin composite monomers/additives in permanent $3 \mathrm{~T} 3$ and three human primary fibroblast cultures. J Biomed Mater Res. 1998;41:474-480.

21. Rakich DR, Wataha JC, Lefebvre CA, Weller RN. Effect of dentin bonding agents on the secretion of inflammatory mediators from macrophages. J Endod. 1999;25:114-117. 
22. Mantellini MG, Botero TM, Yaman P, Dennison JB, Hanks CT, Nor JE. Adhesive resin induces apoptosis and cell-cycle arrest of pulp cells. J Dent Res. 2003;82:592-596.

23. Knobloch LA, Gailey D, Azer S, Johnston WM, Clelland N, Kerby RE. Bond strengths of one- and two-step self-etch adhesive systems. J Prosthet Dent. 2007;97:216-222.

24. Uno S, Inoue H, Finger WJ, Inoue S, Sano H. Microtensile bond strength evaluation of three adhesive systems in cervical dentin cavities. J Adhes Dent. 2001;3:333-341.

25. Hanks CT, Sun ZL, Fang DN, Edwards CA, Wataha JC, Ritchie $\mathrm{HH}$ et al. Cloned 3T6 cell line from CD-1 mouse fetal molar dental papillae. Connect Tissue Res. 1998;37:233-249.

26. Sun ZL, Fang DN, Wu XY, Ritchie HH, Begue-Kirn C, Wataha JC et al. Expression of dentin sialoprotein (DSP) and other molecular determinants by a new cell line from dental papillae, MDPC-23. Connect Tissue Res. 1998;37:251-261.

27. Miyazaki M, Iwasaki K, Onose H. Adhesion of single application bonding systems to bovine enamel and dentin. Oper Dent. 2002;27:88-94.

28. Ferracane JL. Elution of leachable components from composites. J Oral Rehabil. 1994;21:441-452.

29. Koliniotou-Koubia E, Dionysopoulos P, Koulaouzidou EA, Kortsaris AH, Papadogiannis Y. In vitro cytotoxicity of six dentin bonding agents. J Oral Rehabil. 2001;28:971-975.
30. Endo T, Finger WJ, Hoffmann M, Kanehira M, Komatsu M. The role of oxygen inhibition of a self-etch adhesive on selfcure resin composite bonding. Am J Dent. 2007;20:157-160.

31. Heitmann T, Unterbrink G. Direct pulp capping with a dentinal adhesive resin system: a pilot study. Quintessence Int. 1995;26:765-770.

32. Akimoto N, Momoi Y, Kohno A, Suzuki S, Otsuki M, Suzuki S et al. Biocompatibility of Clearfil Liner Bond 2 and Clearfil AP$\mathrm{X}$ system on nonexposed and exposed primate teeth. Quintessence Int. 1998;29:177-188.

33. Hebling J, Giro EM, Costa CA. Biocompatibility of an adhesive system applied to exposed human dental pulp. J Endod. 1999;25:676-682.

34. Kenshima S, Reis A, Uceda-Gomez N, Tancredo Lde L, Filho LE, Nogueira FN et al. Effect of smear layer thickness and $\mathrm{pH}$ of self-etching adhesive systems on the bond strength and gap formation to dentin. J Adhes Dent. 2005;7:117-126.

Correspondence: Dr Yoshiyuki Yasuda, DDS, PhD, Division of Clinical Cariology and Endodontology, Department of Oral Rehabilitation, School of Dentistry, Health Sciences University of Hokkaido, 1757 Kanazawa, Ishikari-Tobetsu, Hokkaido, 061-0293, Japan.

E-mail: yasuda@hoku-iryo-u.ac.jp 